\title{
ANALIZA TROŠKOVA SATA RADA TRAKTORA NA OBITELJSKIM GOSPODARSTVIMA
}

\author{
ANALYSIS OF COST OF WORK OF THE TRACTORS \\ ON FAMILY FARMS
}

\section{Zimmer, L. Šumanovac, T. Jurić, M. Jurišić, Ljubica Ranogajec, I. Plaščak}

\section{SAŽETAK}

U radu su prikazani troškovi sata rada traktora. Istraživanja su provedena na deset obiteljskih gospodarstava na području Osječko - baranjske županije tijekom jedne kalendarske godine. Istraživani su svi bitni činitelji koji utječu na trošak sata rada kod rabljenih i novih traktora. Prikupljeni podaci dobiveni su metodologijom anketno-knjigovodstvenog praćenja. Detaljnom analizom svih činitelja i proračunom dobiven je ukupni trošak sata rada poljoprivrednih strojeva koji su podijeljeni po kategorijama A za traktore snage motora do $75 \mathrm{~kW}$, B za traktore snage motora iznad $75 \mathrm{~kW}$ i C za traktore snage motora iznad $149 \mathrm{~kW}$. U radu se uočava visoki fiksni trošak kod novih traktora i visoki varijabilni trošak kod rabljenih traktora. Ukupni troškovi po satu rada najveći su kod C kategorije rabljenih traktora, dok su najniži troškovi uočeni kod rabljenih traktora A kategorije. Ovaj rad predstavlja prikaz jednog od načina (modela) pomoću kojeg je moguća optimizacija i unaprjeđenje iskorištenja poljoprivredne tehnike.

Ključne riječi: troškovi, traktor, obiteljsko gospodarstvo, QGIS, GIS sustavi

\section{ABSTRACT}

This paper presents the costs of tractor hours. Research was conducted on ten family farms in the Osijek - Baranja County area during one calendar year. All of the factors that affect the cost of working hours for used and new tractors were explored. The collected data were obtained by the methodology of surveying and bookkeeping. With a detailed analysis of all factors and the budget, the total hourly cost of agricultural machines was divided into categories A for tractors power up to $75 \mathrm{~kW}$, B for tractors power above $75 \mathrm{~kW}$ and $\mathrm{C}$ for tractors power above $149 \mathrm{~kW}$. In the paper high fixed cost of new 
tractors and high variable cost of used tractors are noticed. The total hourly labor costs are the highest in the $\mathrm{C}$ category of used tractors, while the lowest costs are observed in the A category used tractors. This paper presents one of the ways (model) that allows optimization and improvement of utilization of agricultural technology.

Keywords: costs, tractor, family farms, QGIS, GIS system

\section{UVOD}

Ratarska proizvodnja, kao najzastupljenija proizvodnja na našim gospodarstvima, predstavlja priliku za uspješno poslovanje gospodarstava. Kako bi se prilika i iskoristila, neophodno je planski i argumentirano izračunati koje proizvodnje su najisplativije i kakvu strukturu rada i prihoda donosi izabrana optimalna struktura proizvodnje, navode Zoranović i sur. 2009.). Dos Reis i sur. (2014.) navode u svojim istraživanjima kako je potrebno razviti model selekcije kod poljoprivrednika i time im pomoći kod nabavke poljoprivredne mehanizacije i postići optimalnu strukturu proizvodnje. Von Pentz (2011.) u svom istraživanju navodi kako tehnologija koja je uključena u mehanizaciju, posebice u traktor, ima značajan utjecaj na troškove proizvodnje, a time i na cijenu prodavača. Al-Suhaibani i sur. (2017.) navode kako su traktori od esencijalne važnosti kao izvor snage u poljoprivredi, gdje se koriste u većini gospodarstava tijekom cijele sezone.

Bez poznavanja troškova, bez njihova planiranja, razvrstavanja, evidentiranja, kontrole i analize ne mogu se izračunavati relevantni pokazatelji uspješnosti poslovanja organizacije. Pokazatelji uspješnosti poslovanja bitni su jer omogućuju donošenje poslovnih odluka temeljenih na činjenicama, a time i upravljanje poslovnim sustavom organizacije navodi Drljača (2003.). Troškovi strojeva su najvažniji fiksni troškovi na većini gospodarstava te male uštede mogu imati veliki utjecaj na profitabilnost navodi URL 1. (2017.). Baranyai (2014.) zaključuje da bi poboljšanje iskorištenja kapaciteta nastalog u okviru aranžmana suradnje moglo pozitivno utjecati na troškove korištenja strojeva kroz smanjenje fiksnih troškova. Liu i sur. (2011.) navode kako se udruženja poljoprivrednika mogu razviti u modernu poljoprivrednu organizaciju koja može zadovoljiti potrebe modernog razvoja poljoprivrede. Fiksni troškovi strojeva uključuju amortizaciju, kamate ulaganja, poreze, osiguranje i stanovanje, dok varijabilni troškovi uključuju troškove popravka i održavanja, plaće i trošak goriva i maziva prema ASABEu (2009.) te Stanišiću i sur. (2014.). 
Trošak strojeva je glavna stavka troškova u poljoprivrednim gospodarstvima u visoko mehaniziranim proizvodnim sustavima. U posljednjih nekoliko godina, strojevi velike snage motora, naprednim tehnologijama, visokim troškovima za rezervne dijelove i popravcima te velikom potrošnjom goriva pridonijeli su još većem povećanju troškova strojeva, navode Sopegno i sur. (2016.), Bochtis i sur. (2014.), Najafi i sur. (2015.) i USDA (2014.).

Racionalno upravljanje proizvodnim troškovima je preduvjet poslovnog uspjeha koji ne podrazumijeva eliminaciju troškova već njihovu optimizaciju u vezi s ostvarenim konačnim učinkom, zaključuju Hadelan i sur. (2016.). Srivasava i sur. (2006.) navode kako troškovi strojeva uključuju troškove vlasništva i radnih operacija, kao i kazne zbog nedostatka pravovremenosti.

Busato i sur. (2014.) i Najafi i sur. (2015.) tvrde kako ne postoji jedinstveni proces procjene troškova strojeva, dok je najprecizniji način njihova procjenjivanja potpuna evidencija stvarnih troškova koja se ne može koristiti za brzi uvid troškova jer je evidentiranje dugotrajan i sistematičan proces koji uključuje matematičko programiranje. Najafi i sur., (2015.) i Lorencowicz i sur. (2007.) u svojim analizama zaključuju kako bi se pravovremeno smanjili troškovi, a preporučuju zajedničko vlasništvo nad strojevima susjednih gospodarstava i razvoj različitih vrsta suradnje sa suvremenom poljoprivrednom tehnologijom. Dhiman i sur. (2015.) navode kako je u poljoprivredi na globalnoj razini potrebna promjena $\mathrm{u}$ mehanizaciji što je zapravo dugoročna strategija za postizanje cilja. Gunnarsson (2008.) izvještava u svojim istraživanjima kako na švedskim poljoprivrednim gospodarstvima, udio troškova strojeva u ukupnom trošku proizvodnje iznosi oko $25 \%$. Korištenje strojeva u poljoprivrednoj proizvodnji usjeva smatra se najskupljim ulaganjem $\mathrm{u}$ proizvodnji kultura nakon troškova nastalih kupovinom poljoprivrednih površina, kako zaključuje Edwards (2015.). U RH prosječna veličina gospodarstva iznosi oko 5 ha i takvo gospodarstvo najčešće posjeduje traktor snage 30 i više $\mathrm{kW}$, odnosno da je prosječna raspoloživa snaga po jednom hektaru preko $6 \mathrm{~kW}$ što ukazuje na nedovoljnu iskorištenost traktora na našim gospodarstvima. U 2016. godini u RH registrirano je oko 112000 traktora od kojih je 350 novih odnosno starih do godinu dana. Nešto manje od 2000 traktora je starih od jedne do pet godina, dok je preko $90 \%$ traktora starije od deset godina. navodi Filipović, 2017. (URL 2.). Troškovi poljoprivredne mehanizacije su vrlo bitan element u kalkulaciji pri proizvodnji ratarskih kultura. Prema raznim literaturnim navodima udio troška mehanizacije u općenitoj proizvodnji je minimalno $30 \%$. Smanjivanjem troškova rada 
poljoprivredne mehanizacije smanjujemo i ukupan trošak poljoprivredne proizvodnje i postajemo konkurentniji na tržištu.

\section{CILJ ISTRAŽIVANJA}

Cilj ovog istraživanja je prikazati troškove rada sata nove i rabljene mehanizacije na području Osječko-baranjske županije na deset poljoprivrednih gospodarstava. U radu su prikazani troškovi i njihov rast zavisno o tipu eksploatacije poljoprivrednih strojeva te pojašnjenje dobivenih vrijednosti troškova.

\section{MATERIJAL I METODE}

U jednogodišnjem istraživanju korištena je metodologija anketnoknjigovodstvenog praćenja koja sadrži podatke o stanju novih i rabljenih strojeva, strukturu poljoprivredne mehanizacije, utrošak goriva i maziva, rezervnih dijelova te redovnih i izvanrednih popravaka. Metodologija je kreirana na Agronomskom fakultetu Sveučilišta u Zagrebu. Prikupljeni podaci dobiveni su istraživanjem i svakodnevnim praćenjem deset obiteljskih poljoprivrednih gospodarstava (OPG-a) tijekom jedne kalendarske godine na području Osječko-baranjske županije. Određeni podatci poput onih o radnim procesima prikupljeni su prilikom eksploatacije poljoprivrednih strojeva i podijeljeni u tri kategorije vučne sile traktora (A - najslabija vučna sila, B - srednja vučna sila i C - najjača vučna sila) zavisno o vučnoj sili stroja (tehnički i eksploatacijski radni učinak, vrijeme zastoja, vrijeme održavanja i sl.). Na slici 1. je prikazana digitalna karta izrađena u GIS aplikaciji otvorenog koda QGIS v3.2 gdje su gospodarstva kategorizirana prema veličinama poljoprivrednih površina. Tom kartom prikazana je prostorna raspodjela svih istraživanih i geolociranih OPG-a. Korištenjem GIS sustava dolazi se do značajne uštede vremena prilikom organizacije i izvođenja radova na poljoprivrednim površinama te kvalitetnijih poljoprivrednih postupaka (Zimmer i sur., 2016.; Jurišić i sur., 2015.; Jurišić i sur., 2018.). 


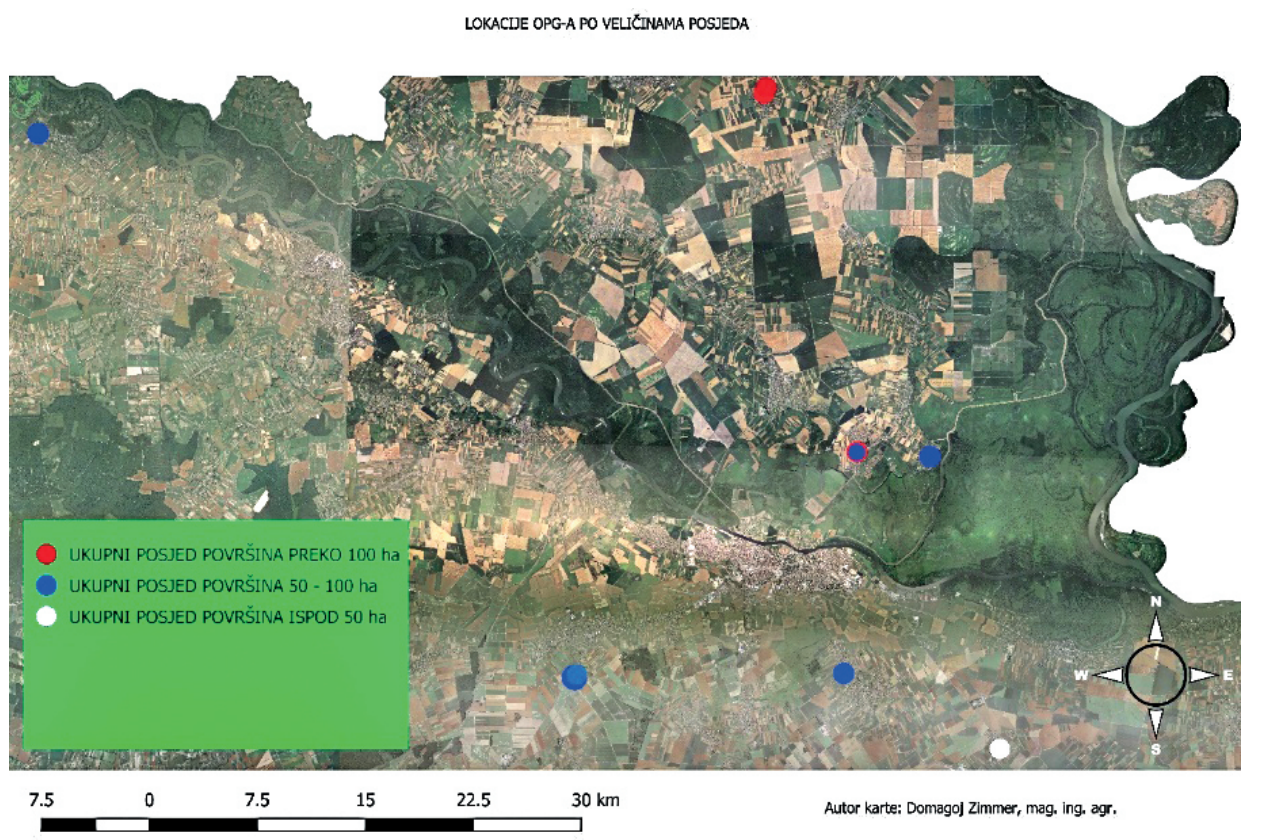

Slika 1. Geolokacije OPG-a prema veličini poljoprivrednih površina

Fig 1 Geolocations of family farms according to the size of agricultural land

U grafikonu 1. prikazane su prosječne starosti traktora za svih 10 OPG-a. Ukupan prosjek starosti traktora za istraživana gospodarstva je 20,71 godina, dok je prosječan broj $\mathrm{kW}$ za istraživana gospodarstva iznosio $248 \mathrm{~kW}$, uz standardnu devijaciju od 156,95 kW i koeficijent varijacije od 63,28\%.

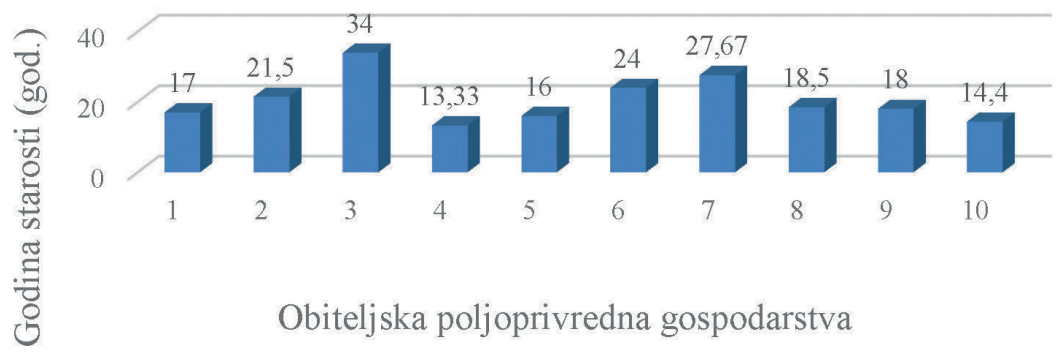

Grafikon 1. Prosjek starosti traktora za istraživana gospodarstva

Graph 1 Average tractor age at explored farms 
U radu su analizirani svi bitni parametri koji imaju direktan utjecaj na troškove rada novih i rabljenih poljoprivrednih strojeva. Za promatranu Osječko-baranjsku županiju i ukupno deset istraživanih OPG-a izračunata je cijena sata rada za nove i rabljene strojeve na osnovi podataka dobivenih iz tehnološke karte biljne proizvodnje i na temelju knjigovodstvenog praćenja koristeći izračunavanje troškova posjedovanja i troškove raspolaganja prema izračunu Karića (2002.). Istraživana gospodarstva nisu imenovana nego su navedena arapskim brojkama od 1. - 10. Izračunate su cijene sata rada u vlastitom gospodarstvu, cijena uslužnog i najamnog rada. Kalkulaciju sata rada čine dvije osnovne skupine troškova:

a.) Fiksni troškovi koji nastaju bez obzira da li se stroj koristi ili ne koristi, a to su amortizacija, kamate na kredit za osnovna sredstva, troškovi investicijskog održavanja, osiguranje osnovnih sredstava, stalni doprinosi i članarine, plaće izravne izrade učinaka, zakupi, najamnine za korištenje poslovnih prostora, troškovi smještaja poljoprivrednih strojeva i koncesija (Ivanković, 2007.) i

b.) Varijabilni troškovi koji imaju drugačiji karakter jer poglavito zavise o intezivnosti korištenja (broju sati rada), stanju, tipu, kapacitetu stroja itd. (Vasiljević i sur., 2005.).

Elementi koji pripadaju fiksnim troškovima su: amortizacija (izračunava se vremenskom linearnom metodom), kamate za nabavku novih poljoprivrednih strojeva na razini od 5,3\%, osiguranje na razini od $1,50 \%$ od nabavne vrijednosti poljoprivrednih strojeva, trošak registracije traktora, kombajna i prikolica, objekti za smještaj poljoprivrednih strojeva na razini od $0,5 \%$ od nabavne vrijednosti poljoprivrednih strojeva (Srivastava i sur. 2006; ASABE American Society of Agricultural and Biological Engineers, 2009.). Varijabilni troškovi što pripadaju fiksnim troškovima prema ASABEu (2009.) su: gorivo i mazivo, troškovi popravka (tekući i investicijski), redovito održavanje i ostali potrošni materijal. Izračunavanje troškova rada novih poljoprivrednih strojeva temelji se na programiranom broju sati rada poljoprivrednih strojeva, $u$ vlastitom gospodarstvu, uslužnom i najamljenom broju sati rada, a temelj za proračun je tehnološka karta biljne proizvodnje dobivena praćenjem obiteljsko poljoprivrednih gospodarstava.

\section{REZULTATI I RASPRAVA}

Na grafikonu 2. uočava se kako su kod 5. OPG-a najveći fiksni troškovi po satu kod rabljenog traktora i to 49,57 kn za A kategoriju traktora i 149,35 kn za B kategoriju traktora (Grafikon 3.), dok je kod C kategorije traktora koju posjeduje samo 4. OPG fiksni trošak po satu rabljenog stroja iznosio 48,20 kn (Grafikon 4.). Na visoku cijenu sata rada u 5. OPG-u direktno utječe nizak broj sati rada uz visoku nabavnu vrijednost. Kod 6. i 7. OPG-a uočava se niska 
cijena sata rada od 4,36 kn za 7. OPG, odnosno 6,33 kn kod 6. OPG-a. Iznimno niska cijena sata rada opravdana je zbog izrazito velikog broja sati rada kod oba gospodarstva te niske nabavne cijene rabljenih strojeva. Preostala obiteljska gospodarstva imala su različite cijene sata rada od 17,99 kn za A kategoriju kod 1. OPG-a (Grafikon 2.) pa sve do 32,54 kn odnosno $60,66 \mathrm{kn}$ za B kategoriju kod 3. OPG-a (Grafikon 3.). 10. OPG posjeduje traktor A kategorije, međutim isto tako ga nije koristilo zbog slabe snage motora i starog datuma proizvodnje. U grafikonu 1. prikazane su prosječne starosti traktora za svih 10 OPG-a. Gilanipoor i sur. (2012.) u svojim istraživanjima u Iranu utvrđuju kako fiksni troškovi po satu iznose 1,43 \$ što je $4,09 \%$ od ukupnog prosječnog fiksnog troška po satu za nove traktore B kategorije, dok varijabilni troškovi po satu iznose 4,11 \$, što je $21,84 \%$ od ukupnog prosječnog varijabilnog troška po satu za nove traktore B kategorije. Dobiveni podaci bitno se razlikuju kod fiksnih troškova zbog puno nižih nabavnih vrijednosti traktora, dok su varijabilni troškovi bitno različiti zbog velikih razlika u cijeni goriva između Europske unije odakle se RH opskrbljuje gorivom i Irana.

Ranogajec i sur. (2013.) i Jurišić i sur. (2011.) u svojim istraživanjima su podijelili traktore na tri kategorije: laki, srednji i teški traktor. Cijena koštanja sata rada za laki traktor je iznosila $86,67 \mathrm{kn}$, za srednji traktor $119,72 \mathrm{kn}$ te za teški traktor $231,36 \mathrm{kn}$. Ako se želi usporediti podatak iz istraživanja na deset OPG-a tada se može uočiti kako su rabljeni traktori A kategorije imali cijenu sata rada 35,41 kn odnosno 40,85\% naspram gore spomenutih, dok su rabljeni traktori B kategorije imali veću cijenu sata rada naspram gore spomenutih podataka, odnosno 142,44 kn. Sito i sur. (2003.) navode kako su fiksni troškovi po satu za rabljeni traktor motorne snage $46,2 \mathrm{~kW}$ iznosili $14,85 \mathrm{kn} / \mathrm{h}$ što je $58,25 \%$ prosječnih fiksnih troškova po satu za rabljene traktore A kategorije dok su za rabljeni traktor motorne snage $83,5 \mathrm{~kW}$ iznosili $11.75 \mathrm{kn} / \mathrm{h}$ što je 11,18 \% od prosječnih fiksnih troškova po satu za rabljene traktore B kategorije. Uspoređujući podatke može se utvrditi kako su današnji fiksni troškovi znatno veći nego kod prijašnje upotrebe poljoprivredne mehanizacije. Sartori i Galletto (1992.) te Cancante i sur. (2013.) zaključuju kako popravak i održavanje uglavnom iznose $10-15 \%$ od ukupnih troškova.

U istraživanim OPG-ima ukupan prosjek starosti traktora je 20,71 godina što je prosječna starost traktora u većini zemalja Europske unije, dok je prema Murphyju i sur. (2010.) prosječna starost traktora u Sjedinjenim Američkim Državama preko 25 godina starosti. U istraživanim OPG-a ukupan broj prosječne raspoložive snage traktora po jedinici poljoprivredne površine je $5,59 \mathrm{~kW} / \mathrm{ha}$, dok je prema Filipoviću, 2017. (URL 2.) prosječna raspoloživa snaga traktora u SAD-u oko $1 \mathrm{~kW} /$ ha korištenog zemljišta, u Njemačkoj oko 2 kW/ha i u Francuskoj oko 3 kW/ha. 


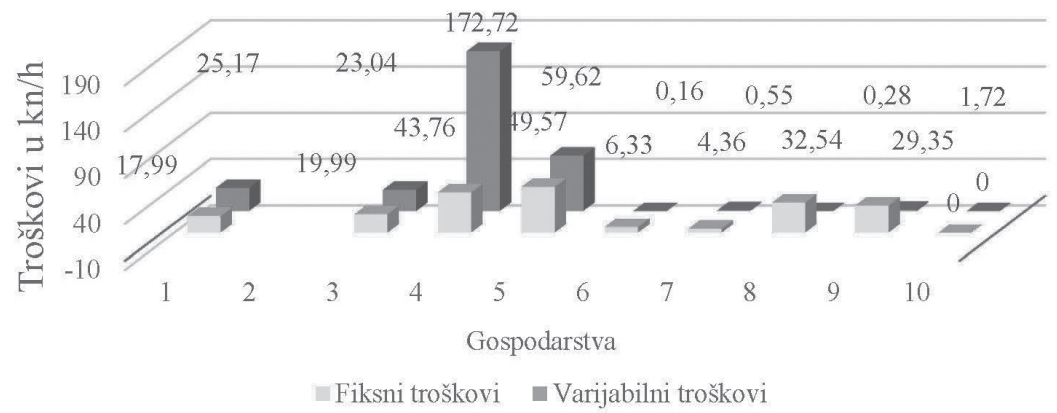

Grafikon 2. Troškovi sata rada rabljenih traktora A kategorije Graph 2 Cost per hour of work of used A category tractors

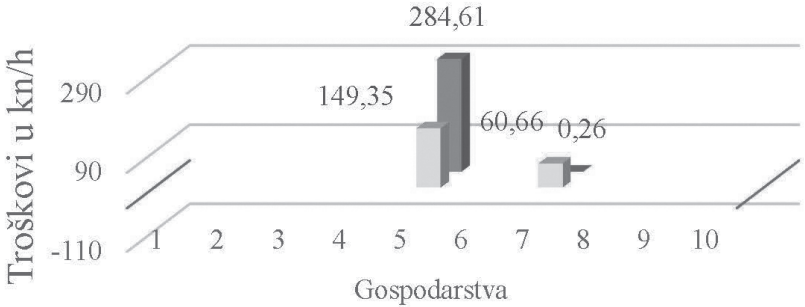

Eiksni troškovi $\quad$ Varijabilni troškovi

Grafikon 3. Troškovi sata rada rabljenih traktora B kategorije Graph 3 Cost per hour of work of used B category tractors

310,07

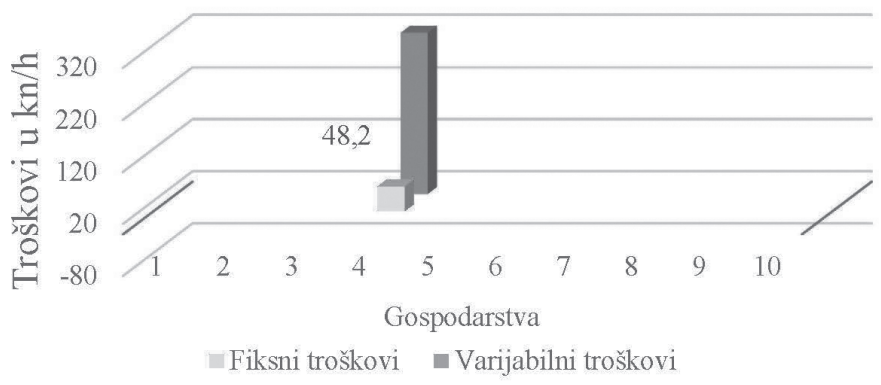

Grafikon 4. Troškovi sata rada rabljenih traktora C kategorije Graph 4 Cost per hour of work of used C category tractors 
$\mathrm{Za}$ nove traktore A kategorije ukupni varijabilni troškovi su iznosili 133,48 kn (Grafikon 5.), dok su se kod B kategorije traktora varijabilni troškovi kretali od 87,66 kn pa sve do 179,86 kn (Grafikon 6.). Prosječni varijabilni trošak za A kategoriju traktora iznosi 133,48 kn, dok za B kategoriju 119,60 kn. Mogu se uočiti visoki varijabilni troškovi koji su nastali pojavom skupih popravaka poljoprivrednih strojeva. U 1. OPG-u može se uočiti niski ukupni varijabilni trošak, što je rezultat male potrošnje kemijske energije i vrlo niskog udjela troška za ostali potrošni materijal koji sudjeluje u formiranju ukupnog varijabilnog troška. U 2. OPG-u može se uočiti najveći ukupni trošak po satu rada u iznosu od 92,66 za A kategoriju traktora i priključnih strojeva, dok je u 9. OPG-u za B kategoriju traktora najveći ukupni trošak pa satu rada iznosio 180,10 kn. Promatrajući ukupne troškove po satu rada najveći su bili kod novih traktora A kategorije u iznosu od 359,62 kn i kod rabljenih traktora C kategorije u iznosu od 358,27 kn, dok su najniži bili kod rabljenih traktora A kategorije u iznosu od 68,99. Najveći fiksni troškovi po satu rada bili su kod novih traktora B kategorije u iznosu od 242,67 kn, dok su najniži bili u istoj kategoriji (B) kod rabljenih traktora u iznosu od 57,60 kn odnosno 23,73 \%. Najveći varijabilni troškovi mogu se uočiti kod rabljenih traktora $\mathrm{C}$ kategorije u iznosu od 310,07 kn, dok je kod rabljenih traktora A kategorije vidljiv najniži varijabilni trošak u iznosu od 47,68 kn tj. 15,37 \% od najvećeg varijabilnog troška rabljenog traktora $\mathrm{C}$ kategorije.

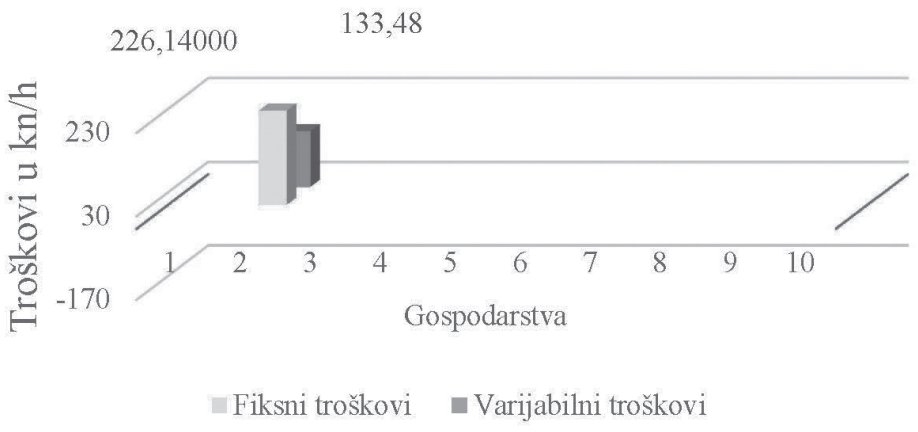

Grafikon 5. Troškovi sata rada novih traktora A kategorije

Graph 5 Cost per hour of work of new A category tractors 


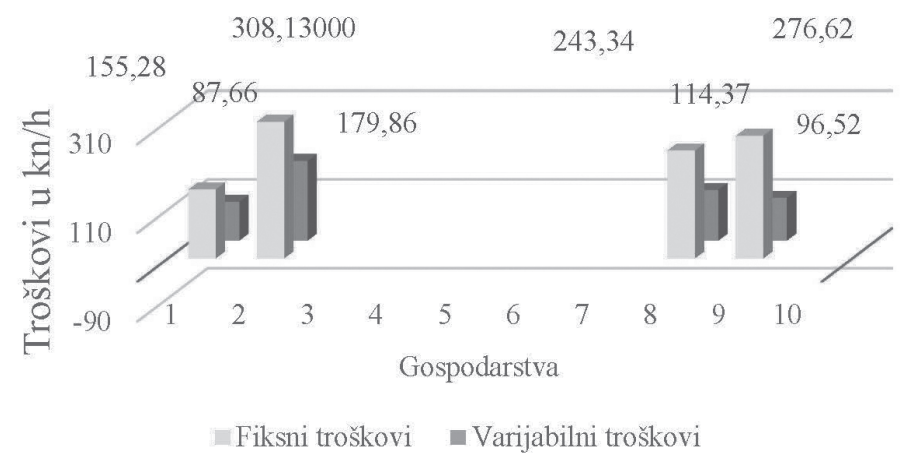

Grafikon 6. Troškovi sata rada novih traktora B kategorije

Graph 6 Cost per hour of work of new B category tractors

\section{ZAKLJUČCI}

Usporedbom novih i rabljenih strojeva može se uočiti kako novi traktori A i B kategorije imaju veći fiksni trošak naspram varijabilnog, što je i očekivano jer su kod novih strojeva velika izdavanja financijskih sredstava zbog amortizacije, osiguravanja, kamata itd. Ukupni godišnji fiksni troškovi za nove traktore A kategorije iznose $44.718,51 \mathrm{kn}$, dok su ukupni fiksni troškovi za rabljenje traktore iste kategorije (A) manji za 25,68 \%, odnosno 11.485,25 kn. Kod traktora B kategorije za ukupne fiksne troškove novih strojeva potrebno je izdvojiti 54.149,29 kn, odnosno 38,68 \% manje za rabljene traktore iste kategorije (B) tj. 20.945,57 kn. Kod najveće kategorije traktora (C) može se uočiti kako niti jedno OPG nije posjedovalo novi traktor, stoga je moguće samo prikazati fiksne troškove za rabljeni traktor C kategorije u iznosu od $27.043,33 \mathrm{kn}$, te vrlo visoki varijabilni trošak u iznosu od 173.961,65 kn. Razlozi jako visokog varijabilnog troška kod 4. OPG-a su dva velika popravka traktora C kategorije koji su izravno utjecali na visinu varijabilnih troškova. Ako se promatra postotni udjel varijabilnih troškova novih traktora naspram ukupnih troškova, tada varijabilni troškovi za A kategoriju traktora iznose $37,11 \%$, a za B kategoriju traktora $46,52 \%$. Postotni udjel varijabilnih troškova rabljenih traktora naspram ukupnih troškova za A kategoriju je $62 \%$, dok je za B kategoriju 57,35\%. Kod rabljenih traktora najveće kategorije (C) postotni udjel varijabilnih troškova rabljenih traktora naspram ukupnih troškova iznosi $86,54 \%$. Najveći ukupni troškovi po godini su kod C kategorije rabljenih traktora te iznose 201.004,98 kn, zatim kod B kategorije novih traktora u iznosu od 101.254,49 kn. Najniži ukupni troškovi po godini su kod A kategorije 
rabljenih traktora $\mathrm{u}$ iznosu od $30.230,17 \mathrm{kn}$, što je razumljivo jer se $\mathrm{u}$ istraživanim gospodarstvima tijekom godine dana traktori A kategorije manje angažiraju zbog nižie snage i slabijih vučnih sposobnosti. Također A kategorija traktora nije imala veće kvarove niti učestalije tehničke servise i ostala održavanja te su time i ukupni troškovi niži. Promatrajući varijabilne troškove logično je da su kod $\mathrm{C}$ kategorije rabljenih traktora bili najveći u iznosu od $310,07 \mathrm{kn}$, dok su najniži bili kod rabljenih traktora A kategorije u iznosu od 47,68 kn. Ovo je prikaz jednog načina troškova koštanja koji bi se mogao primijeniti u širem području i sa znatno većim brojem OPG-a kroz duže vrijeme, te je mogući model po kojem bi se mogli izračunati troškovi sata rada. Ovaj rad predstavlja prikaz jednog od načina (modela) pomoću kojeg je moguća optimizacija i unaprjeđenje iskorištenja tehnike. Prvi korak je prikupljanje stvarnih podataka (na osnovi čega su izračunati troškovi), a potom je moguće prikupljene podatke prostorno analizirati na način da se svakom gospodarstvu s pripadajućim podacima o troškovima pridruže i prostorne vrijednosti (lokacija samog gospodarstva, udaljenost pojedine čestice od gospodarstva, blizina važnijih prometnica i slično), te se pristupi geostatističkim metodama analize.

\section{LITERATURA}

1. Al-Suhaibani, S. A., Wahby, M. F. (2017.): Farm tractors breakdown classification, Journal of the Saudi Society of Agricultural Sciences, 16(3), 294-298.

2. ASABE D497.6 (2009.): Agricultural Machinery Management Data, In: ASABE Standards. St. Joseph, Mich.: ASABE.

3. Baranyai, Z., Szabó, G. G., Vásáry, M. (2014.): Analysis of machine use in Hungarian agriculture-Is there any future for machinery sharing arrangements. Ann. Pol. Assoc. Agric. Agribus. Econ, 16, 24-30.

4. Bochtis, D.D., Sørensen, C.G.C., Busato, P. (2014.): Advances in agricultural machinery management: a review. Biosyst. Eng. 126, 69-81.

http://dx.doi.org/10.1016/j. biosystemseng.2014.07.012.

5. Busato, P., Berruto, R. (2014.): A web-based tool for biomass production systems. Biosyst. Eng. 120, 102-116.

http://dx.doi.org/10.1016/j. biosystemseng.2013.09.002

6. Dhiman, M., Dihman, J. (2015): Infusion of farm mechanization technologies in Indian agricultre: progres and impact. 
D. Zimmer i sur.: Analiza troškova sata rada traktora na obiteljskim gospodarstvima

7. dos Reis, AV (dos Reis, Angelo V.), Machado, ALT (Machado, Antonio L. T.), Gomes, MC (Gomes, Mario C.), Andersson, NLM (Andersson, Norberto L. M.), Machado, RLT (Machado, Roberto L. T.). (2014.): A multicriteria mdel to assess tractors use din family agriculture, Engenharia Agricola.

8. Drljača, M. (2003.): Karakteristike troškova kvaliteta, Kvalitet broj 7-8, str. 6-9, Infomart, Zagreb.

9. Edwards W (2015.): PM-710 estimating Farm Machinery Costs, Iowa State University Extension, Retrieved from http://www.econ.iastate.edu/research/extension/p7155on

10. Gilanipoor, N., Najafi, A., Heshmat Alvaezin, S. M. (2012.): Productivity and cost of farm tractor skidding. J For Sci, 58(1), 21-26.

11. Gunnarsson, L. (2008.): Swedish utility achieves energy balance, World Water and Environmental Engineering, 31(2), 19-24.

12. Hadelan, L., Jež Rogelj, M., Grgić, I., Zrakić, M. (2016.): Scenarijska analiza financijskih pokazatelja proizvodnje krumpira. Glasnik Zaštite Bilja, 39(6), $38-45$.

13. Jurišić, M., Šumanovac, L., Zimmer, D., Barač, Ž. (2015.): Tehnički i tehnološki aspekti pri zaštiti bilja u sustavu precizne poljoprivrede, Poljoprivreda, 21(1), 75-81.

14. Jurišić, M., Plaščak, I., Zimmer, D., Barač, Ž., Rapčan, I. (2018.): Modern Navigation System DGPS as a Function of Saving in Agriculture, Tehnički vjesnik, 25(4), 1067-1074.

15. Jurišić, M., Kanisek, J., Turkalj, D., Nosal, N., Galić-Subašić Daria (2011.): Važniji tehnološki činitelji i ekonomski rezultati pri uzgoju sjemenskog suncokreta na Poljoprivrednom institutu u Osijeku. In Proceedings. 46th Croatian and 6th International Symposium on Agriculture. Opatija. Croatia (Vol. 451, p. 455).

16. Liu, J., Q, C. J. (2011.): An Analysis of Dynamic Mechanism and Improving Measures of Agricultural Cooperatives' Institutional Innovation in China [J]. Research of Agricultural Modernization, 2, 019.

17. Lorencowicz, E., Uziak., J. (2007.): Organization of mechanization in selected family farms, II International Symposium "Farm Machinery and Process Management in Sustainable Agriculture" Lublin, Poland, 93-96.

18. Murphy, D. J., Myers, J., McKenzie Jr, E. A., Cavaletto, R., May, J., Sorensen, J. (2010.): Tractors and rollover protection in the United States, Journal of agromedicine, 15(3), 249-263. 
D. Zimmer i sur.: Analiza troškova sata rada traktora na obiteljskim gospodarstvima

19. Najafi, B., Torabi Dastgerduei, S. (2015.): Optimization of Machinery Use on Farms with Emphasis on Timeliness Costs. Journal of Agricultural Science and Technology, 17(3), 533-541.

20. Ranogajec, L., Kanisek, J., Deže, J. (2013.): Ekonomski rezultati proizvodnje soje u Hrvatskoj. zbornik radova, 49, 171-175.

21. Sito, S., Grgić, Z., Barčić, J., Ivančan, S., Fabijanić, G. (2003.): Economy of pumpkin seed production at different soil tillage systems. Agriculturae conspectus scientificus, 68(1), 27-32.

22. Sopegno, A., Calvo, A., Berruto, R., Busato, P., Bocthis, D. (2016.): A web mobile application for agricultural machinery cost analysis, Computers and electronics in agriculture, 130, 158-168.

23. Srivastava, A.K., C. E. Goering, R. P. Rohrbach, D. R. Buckmaster (2006.): Machinery Selection and Management. Chapter 15 in Engineering Principles of Agricultural Machines, $2^{\text {nd }}$ ed., 525-552. St. Joseph, MI: ASABE. Copyright American Society of Agricultural and Biological Engineers.

24. Stanišić, N., Knežević, G. (2014.): Prelomna tačka: Akademska igračka ili upotrebljiva alatka finansijskog analitičara. In Proceedings of the 1 st International Scientific Conference-FINIZ 2014 (pp. 45-47).

25. USDA. (2014.). Characteristics and production costs of U.S. corn farms, including organic, 2010. Economic Research Service. Washington, D.C.: United States Department of Agriculture. http://www.ers.usda.gov/media/1673846/eib128.pdf.

26. Von Pentz, M. (2011.): On our way to a global company. In: Plenary Lecture of the $69^{\text {th }}$ Conference Land Technik-AgEng, Hannover, Germany, 11-12th November.

27. Zimmer, D., Jurišić, M., Plaščak, I., Barač, Ž. (2016.): Tehnički i tehnološki čimbenici gnojidbe primjenom GIS tehnologije u poljoprivredi, Agronomski glasnik: Glasilo Hrvatskog agronomskog društva, 78(1), 27-40.

28. Zoranovic, T., Berkovic, I. and Letic, D. (2009.): Optimized model for crop farming. Agrieconomica, 116.

29. URL 1: Welcome to The Lothian Machinery Ring's Website. Home page address: http://www.lothianmachineryring.co.uk/index.html (2018-10-09)

30. URL 2: Prosječna starost traktora je oko 30 godina, a preko 90 posto ih je starije od deset godina. Home page address:

https://www.agrobiz.hr/agrovijesti/prosjecna-starost-traktora-je-oko-30godina-a-preko-90-posto-ih-je-starije-od-deset-godina-4273 (2018-10-30) 
Adrese autora - Author's addresses:

Domagoj Zimmer, mag. ing. agr., e-mail: dzimmer@pfos.hr, prof. dr. sc. Luka Šmanovac, prof. dr. sc. Tomislav Jurić, prof. dr. sc. Mladen Jurišić, prof. dr. sc. Ljubica Ranogajec doc. dr. sc. Ivan Plaščak

Fakultet agrobiotehničkih znanosti Osijek, Sveučilište J. J. Strossmayera u Osijeku, Vladimira Preloga 1, 31000 Osijek, Hrvatska
Primljeno - Received:

30.06.2018. 